\title{
Pronociceptive Actions of Dynorphin Maintain Chronic Neuropathic Pain
}

\author{
Zaijie Wang, ${ }^{1}$ Luis R. Gardell, ${ }^{1}$ Michael H. Ossipov, ${ }^{1}$ Todd W. Vanderah, ${ }^{1}$ Miles B. Brennan, ${ }^{4}$ \\ Ute Hochgeschwender, ${ }^{5}$ Victor J. Hruby, ${ }^{2}$ T. Phil Malan Jr, ${ }^{1,3}$ Josephine Lai, ${ }^{1}$ and Frank Porreca ${ }^{1,3}$
}

Departments of ${ }^{1}$ Pharmacology, ${ }^{2}$ Chemistry, and ${ }^{3}$ Anesthesiology, University of Arizona Health Sciences Center, Tucson, Arizona 85724, ${ }^{4}$ Eleanor Roosevelt Institute, Denver, Colorado 80206, and 5evelopmental Biology Program, Oklahoma Medical Research Foundation, Oklahoma City, Oklahoma 73104

\begin{abstract}
Whereas tissue injury increases spinal dynorphin expression, the functional relevance of this upregulation to persistent pain is unknown. Here, mice lacking the prodynorphin gene were studied for sensitivity to non-noxious and noxious stimuli, before and after induction of experimental neuropathic pain. Prodynorphin knock-out (KO) mice had normal responses to acute nonnoxious stimuli and a mild increased sensitivity to some noxious stimuli. After spinal nerve ligation (SNL), both wild-type (WT) and KO mice demonstrated decreased thresholds to innocuous mechanical and to noxious thermal stimuli, indicating that dynorphin is not required for initiation of neuropathic pain. However, whereas neuropathic pain was sustained in WT mice, KO mice showed a return to baselines by post-SNL day 10. In WT mice, SNL upregulated lumbar dynorphin content on day 10 , but not day 2, after injury. Intrathecal dynorphin antiserum reversed neuropathic pain in WT mice at post-SNL day 10
\end{abstract}

(when dynorphin was upregulated) but not on post-SNL day 2; intrathecal MK-801 reversed SNL-pain at both times. Opioid ( $\mu$, $\delta$, and $\kappa$ ) receptor density and G-protein activation were not different between WT and KO mice and were unchanged by SNL injury. The observations suggest (1) an early, dynorphinindependent phase of neuropathic pain and a later dynorphindependent stage, (2) that upregulated spinal dynorphin is pronociceptive and required for the maintenance of persistent neuropathic pain, and (3) that processes required for the initiation and the maintenance of the neuropathic pain state are distinct. Identification of mechanisms that maintain neuropathic pain appears important for strategies to treat neuropathic pain.

Key words: prodynorphin; dynorphin; neuropathic pain; opioid receptors; spinal nerve injury; nociception; gene deletion; gene knockout; transgenic; mouse
Peripheral nerve damage can elicit abnormal pain characterized in part by hyperalgesia where noxious stimuli are perceived as more painful, and allodynia where normally innocuous stimuli elicit pain (Ossipov et al., 1999). The clinical efficacy of local anesthetics, anti-arrhythmic, and anti-epileptic drugs (Devor and Seltzer, 1999) supports the concept that such pain critically depends on sustained afferent discharge of nerves. Data from experimental models of neuropathic pain support the importance of discharge of injured or adjacent nerve fibers as critical for eliciting the behavioral signs of nerve injury-induced pain (Kajander and Bennett, 1992; Malan et al., 2000). Recent studies have shown that the rate of discharge of injured nerves declines significantly with time after the injury (Han et al., 2000; C. Liu et al., 2000; X. Liu et al., 2000). Although tonic discharge continues in the postinjury state, the decreased firing rate of the afferents does not appear consistent with many behavioral reports that demonstrate that nerve injury-induced pain persists essentially unchanged for many weeks (Chaplan et al., 1994; Bian et al., 1995). These findings raise the possibility that although the pain state depends on some level of abnormal afferent discharge, the processes that

\footnotetext{
Received Sept. 22, 2000; revised Dec. 6, 2000; accepted Dec. 19, 2000.

This study was supported by National Institute on Drug Abuse DA 11823 . We thank Drs. Shou-wu Ma, En-Tan Zhang, and Chengmin Zhong for their technical assistance.

J.L. and F.P. contributed equally to this work.

Correspondence should be addressed to Dr. Frank Porreca, Department of Pharmacology, University of Arizona Health Sciences Center, Tucson, AZ 85724. E-mail: FRANKP@U.ARIZONA.EDU.

Copyright (C) 2001 Society for Neuroscience $0270-6474 / 01 / 211779-08 \$ 15.00 / 0$
}

initiate neuropathic pain state may differ from those that maintain such pain.

Neuropathic and other chronic (e.g., inflammatory) pain states are associated with increased spinal dynorphin expression (Iadarola et al., 1988; Dubner and Ruda, 1992; Bian et al., 1999; Malan et al., 2000). Whereas dynorphin is an endogenous opioid with activity at $\kappa$ opioid receptors (Goldstein et al., 1979), many of its effects are blocked by MK-801 but not naloxone, implicating direct or indirect interaction with NMDA receptors (Massardier and Hunt, 1989; Skilling et al., 1992; Lai et al., 1998; Tang et al., 1999). Intrathecal dynorphin injection produces behavioral signs that mimic nerve injury-induced pain (Vanderah et al., 1996; Laughlin et al., 1997) and that are blocked by MK-801 pretreatment. The mechanisms of such acute activity of dynorphin in vivo and the relevance of its upregulation in prolonged pain states is not well understood. However, the observation that intrathecal administration of an antiserum to dynorphin $\mathrm{A}_{(1-17)}$ reverses neuropathic pain in nerve-injured rats (Malan et al., 2000) and mice (Ibrahim et al., 1999) has led us to hypothesize that upregulated or pathological levels of spinal dynorphin may play a pronociceptive role by maintaining "central sensitization" in the postnerve injury state.

This hypothesis has been tested in the present study using a transgenic mouse strain in which the gene encoding prodynorphin has been deleted, resulting in mice that do not produce dynorphin (Sharifi et al., 2001). The responses of these prodynorphin knockout $(\mathrm{KO})$ mice to innocuous stimuli and to acute and tonic nociception, were compared with those of wild-type (WT) litter- 
mates before and after spinal nerve ligation injury (SNL). Our findings demonstrate that although the actions of dynorphin are not required for the initiation of the neuropathic pain state, its presence is critical for the maintenance of such abnormal, nerve injury-induced pain.

\section{MATERIALS AND METHODS}

Animals. Progeny of progenitor $129 / \mathrm{SvEv}$-Tac mice were used in this study. They were heterozygous at the prodynorphin gene with one wild-type allele $(+)$ and one null allele $(-)$. In null allele $(-)$, the coding region and $1 \mathrm{~kb}$ of the $3^{\prime}$ untranslated region of the prodynorphin gene were deleted by the replacement of exons 3 and 4 with a neomycin cassette pAB5 (Sharifi et al., 2001). Male mice that were homozygous prodynorphin knock-out $(\mathrm{KO})(-/-)$ and littermates that were homozygous wild-type (WT) $(+/+)$ were used. Both genotypes were viable and showed normal growth and reproduction. Genotyping of litters was initially performed with PCR and confirmed by Southern transblot. Subsequently, mice were routinely genotyped by PCR using a set of prodynorphin primers ( $5^{\prime}$-CAG GAC CTG GTG CCG CCC TCA GAG$3^{\prime}, 5^{\prime}$-CGC TTC TGG TTG TCC CAC TTC AGC-3'; these yield a 500 bp product) and neo primers (5'-ATC CAG GAA ACC AGC AGC GGC TAT-3', 5'-ATT CAG ACA CAT CCC ACA TAA GGA CA-3'; these yield a 1200 bp product). Each mouse was genotyped twice using DNA from two separate extractions from the tail tissue samples. The investigators performing the biochemical and behavioral tests were blind to the genotype of the mice. All breeding and testing procedures were performed in accordance with the policies and recommendations of the International Association for the Study of Pain and the National Institutes of Health guidelines for the handling and use of laboratory animals and approved by the Institutional Animal Care and Use Committee of the University of Arizona.

Immunohistochemistry. Tissue preparation and immunohistochemical staining of spinal cord tissues from WT and KO mice were performed according to that previously described (Vanderah et al., 2001). Frontal frozen sections $(30 \mu \mathrm{m})$ were prepared from the spinal cord lumbar enlargement and immunostained for prodynorphin (guinea pig antiprodynorphin antiserum 1:40,000; gift from Dr. Robert Elde, University of Minnesota, St. Paul, MN). In addition, groups of three prodynorphin WT or KO mice were subjected to sham or SNL surgery and killed at day 14 after surgery. The lumbar spinal cords from these mice were immunolabeled with a rabbit anti- $\mu$ opioid receptor antibody (1:20,000; gift from Dr. Robert Elde) or an antiserum for PKC $\gamma$ (rabbit anti-PKC $\gamma$, 1:10,000; Santa Cruz Biotechnology, Santa Cruz, CA). The sections were processed with a biotinylated goat anti-guinea pig (prodynorphin) or goat anti-rabbit ( $\mu$ opioid receptor and $\mathrm{PKC} \gamma$ ) IgG secondary antibody, followed by the avidin-biotin horseradish peroxidase (HRP) complex (ABC kit; Vector Laboratories, Burlingame, CA) and developed with diaminobenzidine (Fast DAB sets; Sigma, St. Louis, MO). The sections were then mounted on glass slides and coverslipped with DPX. Transmitted light images were acquired using a Nikon E800 microscope outfitted with a plan apo $20 \times$ objective lens and a Hamamatsu C5810 color CCD camera. The digitized output of the camera was acquired with Adobe Photoshop.

Western analysis of the $\kappa$ opioid receptor. The ipsilateral (i.e., left) halves of the lumbar spinal cord from sham or nerve-ligated mice were dissected and frozen on dry ice. Tissues from three mice of the same experimental group were pooled and homogenized with a glass homogenizer in RIPA buffer (1\% NP-40, $0.5 \%$ sodium deoxycholate, $0.1 \%$ SDS, 5 mM EDTA in PBS, $\mathrm{pH}$ 7.4) (3 ml/gm wet weight) in the presence of protease inhibitors $[0.05 \mathrm{mg} / \mathrm{ml}$ bestatin, $0.05 \mathrm{mg} / \mathrm{ml}$ leupeptin, $0.05 \mathrm{mg} / \mathrm{ml}$ pepstatin, and $0.1 \mathrm{mg} / \mathrm{ml}$ phenylmethylsulfonylfluoride (PMSF)]. The homogenates were incubated at $4^{\circ} \mathrm{C}$ for $2 \mathrm{hr}$, and the soluble fraction was separated by centrifugation $(45,000 \times g, 60 \mathrm{~min})$. Protein content in the supernatant was determined by the Lowry method. Samples $(15 \mu \mathrm{g}$ of protein) were separated by $8 \%$ SDS-PAGE and electrotransferred onto nitrocellulose membrane. The membrane was preblocked in $5 \%$ nonfat milk in Tris $(20 \mathrm{~mm})$ buffer saline, $\mathrm{pH} 7.6$, with $0.1 \%$ Tween 20 and incubated with a rabbit anti- $\kappa$ opioid receptor antibody (1:1500; Upstate Biotechnology, Lake Placid, NY). The membrane was washed and incubated with a donkey anti-rabbit IgG-HRP conjugate (1:1000), washed, and developed for chemiluminescence detection (ECL; Amersham, Piscataway, $\mathrm{NJ}$ ). The membrane was then stripped and reprobed with a goat anti-actin antibody (1:200; Santa Cruz Biotechnology) and anti-goat HRP-conjugated secondary antibody and developed as above. ECL- detected bands were digitized and analyzed for relative intensity using MetaMorph (Universal Imagining, West Chester, PA).

Enzyme immunoassay for the quantitative analysis of dynorphin. Spinal dynorphin content was assayed as previously described (Malan et al., 2000) using the dorsal ipsilateral quadrant of the lumbar spinal cord from sham-operated or SNL mice. Content was evaluated either 2 or $10 \mathrm{~d}$ after sham or SNL injury; the latter time point was chosen on the basis of peak SNL-induced spinal dynorphin levels in rats (Malan et al., 2000). Tissue was extracted in $1 \mathrm{M}$ acetic acid, and the dynorphin content in the extracts was quantitated using a commercial enzyme immunoassay system (Peninsula Laboratories, Belmont, CA) and a standard curve constructed from known concentrations of dynorphin $A_{(1-17)}$. The dynorphin antiserum used recognizes dynorphin $\mathrm{A}_{(1-17)}$ and a number of its fragments (as short as dynorphin $\mathrm{A}_{(1-12)}$ ), but has no affinity for $\alpha$-neoendorphin, dynorphin $\mathrm{B}, \beta$-endorphin, $\left[\mathrm{Leu}^{5}\right]-$ or $\left[\mathrm{Met}^{5}\right]$ enkephalin, or for dynorphin fragments shorter than dynorphin $A_{(1-12)}$. Protein content in the extracts was determined by the Coomassie Plus Protein assay (Pierce, Rockford, IL).

Radioligand binding analysis for opioid receptors. Brain membranes were prepared from the whole brains of three mice from the same experimental group by homogenizing the tissues with the Polytron in 50 $\mathrm{mm}$ Tris, $\mathrm{pH} 7.4$, and centrif uging at $45,000 \times g$ for $20 \mathrm{~min}$ at $4^{\circ} \mathrm{C}$. The crude membrane extracts were washed twice in the Tris buffer. Protein content was determined by the Lowry method. Membrane protein (20 $\mu \mathrm{g})$ was incubated with 12 concentrations of $\left[{ }^{3} \mathrm{H}\right]$ diprenorphine $(59$ $\mathrm{Ci} / \mathrm{mmol}$; NEN, Boston, $\mathrm{MA}$ ) in $50 \mathrm{~mm}$ Tris buffer, $\mathrm{pH} 7.4$, containing $1 \mathrm{~mm}$ EDTA, $1 \mathrm{~mm}$ dithiothreitol, $0.1 \mathrm{~mm}$ PMSF, and $0.5 \%$ bovine serum albumin (BSA) at $25^{\circ} \mathrm{C}$ for $3 \mathrm{hr}$. Reaction was terminated by rapid filtration through Whatman (Maidstone, UK) GF/B filters presoaked in polyethylenimine and washed with $3 \times 4 \mathrm{ml}$ of ice-cold PBS. Nonspecific binding was defined as that in the presence of $10 \mu \mathrm{M}$ naloxone. Radioactivity was quantitated by liquid scintillation counting. The $K_{\mathrm{D}}$ and $B_{\max }$ values were calculated by nonlinear least squares analysis (GraphPad Prism, San Diego, CA).

Opioid mediated $\gamma-\left[{ }^{35} S J G T P\right.$ binding in spinal cord. Determination of $\gamma$ - $\left.{ }^{35} \mathrm{~S}\right] \mathrm{GTP}$ binding in spinal cord membranes prepared from naive or nerve-ligated mice was performed as previously described with slight modifications (Porreca et al., 1998). The ipsilateral half of the lumbar spinal cords from three mice in the same group were pooled for membrane extraction as above. Membranes ( $20 \mu \mathrm{g}$ of protein) were incubated with $0.1 \mathrm{nM} \gamma-\left[{ }^{35} \mathrm{~S}\right] \mathrm{GTP}(1000-1500 \mathrm{Ci} / \mathrm{mmol}$; NEN $)$ in a final volume of $1 \mathrm{ml}$ of reaction buffer (50 mM HEPES, pH 7.4, $100 \mathrm{~mm} \mathrm{NaCl}, 1 \mathrm{~mm}$ EDTA, $5 \mathrm{mM} \mathrm{MgCl}_{2}, 20 \mu \mathrm{M}$ GDP, $1 \mathrm{~mm}$ dithiothreitol, and $0.1 \%$ BSA) in the presence of opioid receptor subtype-specific agonists for $60 \mathrm{~min}$ at $25^{\circ} \mathrm{C}$. The agonists (concentration range, $0.1 \mathrm{pM}$ to $100 \mu \mathrm{M}$ ) were: $\left[\mathrm{D}-\mathrm{Ala}^{2}, \mathrm{NMePhe}^{4}-\mathrm{Gly}_{\mathrm{ol}}{ }^{5}\right.$ ]enkephalin (DAMGO), SNC80 and U69,593 for $\mu, \delta$, and $\kappa$ opioid receptors, respectively. Basal level of binding was defined as the amount bound in the absence of agonist. Nonspecific binding was determined in the presence of $10 \mu \mathrm{M}$ unlabeled GTP $\gamma \mathrm{S}$. Reactions were terminated by rapid filtration through Whatman GF/B filters (presoaked in reaction buffer), followed by $4 \times 4 \mathrm{ml}$ of ice-cold wash buffer (50 mm Tris, $5 \mathrm{~mm} \mathrm{MgCl}_{2}$, and $100 \mathrm{~mm} \mathrm{NaCl}, \mathrm{pH} 7.4$ ). The membrane-bound $\gamma$-[ $\left.{ }^{35} \mathrm{~S}\right] \mathrm{GTP}$ was determined by liquid scintillation counting. The $\mathrm{EC}_{50}$ and $E_{\max }$ values were calculated by nonlinear least squares analysis (GraphPad Prism).

Behavioral tests. High-threshold thermal nociception was evaluated by the following methods: (1) tail immersion test by dipping the distal half of the tail into a water bath maintained at 48,52 , or $55^{\circ} \mathrm{C}$ and recording the latency to a rapid tail flick response. A 15, 12, and $10 \mathrm{sec}$ cutoff was applied to 48,52 , or $55^{\circ} \mathrm{C}$ test, respectively, to prevent tissue injury; (2) paw withdrawal latency to a radiant heat source applied to the plantar surface of the paw of mice as previously described (Hargreaves et al., 1988). Naive wild-type mice respond to lower and higher stimulus intensities with appropriate changes in latency; the response at the lower intensity stimulation was $20 \pm 0.42 \mathrm{sec}$ whereas at the higher intensity stimulus the response latency was $12 \pm 0.32 \mathrm{sec}$. A maximal cutoff of 40 sec was used to prevent tissue damage; (3) a hot-plate test by placing the animal in a glass cylinder on a heated plate with temperature controlled to 52 or $55^{\circ} \mathrm{C}$ and determining the latency to hindpaw licking. A cutoff time was set at $45 \mathrm{sec}$ for $52^{\circ} \mathrm{C}$ or $30 \mathrm{sec}$ for $55^{\circ} \mathrm{C}$ hot plate to prevent injury. Non-noxious sensory thresholds of the mice were determined by paw withdrawal latency to probing with a series of calibrated (0.02-2.34 gm on a logarithmic scale) von Frey filaments ("up and down" method) according to Chaplan et al. (1994) and analyzed using a Dixon (1980) nonparametric test and expressed as the mean withdrawal threshold. 


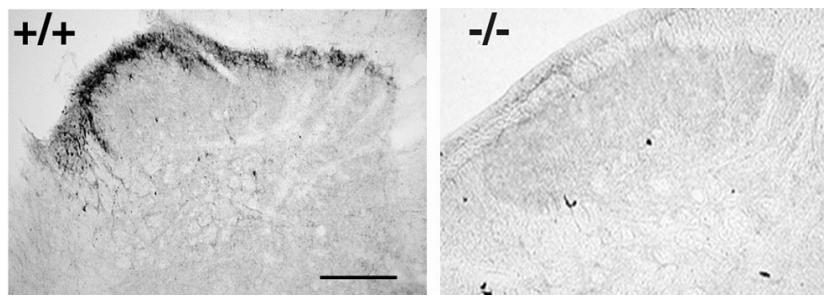

Figure 1. Prodynorphin immunostaining in spinal cord tissues of wildtype $(+/+)$ and prodynorphin knock-out $(-/-)$ mice. Prodynorphin immunoreactivity was primarily seen in the superficial dorsal horn of wild-type mice, but was not detectable in prodynorphin knock-out mice. Scale bar, $200 \mu \mathrm{m}$.

Formalin test. Tonic inflammatory pain was induced in groups of 14 mice by a subcutaneous injection of $20 \mu \mathrm{l}$ of $2 \%$ formalin solution in the dorsal surface of the right hindpaw. Flinching of the paw was counted in bins of 5 min each, starting with the formalin injection and ending after $75 \mathrm{~min}$. The formalin flinch test produces a distinct biphasic response over time with flinching behavior appearing in two phases. To quantify the flinch response over the first and second phases, the total number of flinches occurring between 0 and $15 \mathrm{~min}$ and between 15 and 75 min were summed, respectively, giving a cumulative distribution over time.

$S N L$. SNL was performed based on that previously described for rats (Kim and Chung, 1992). Groups of eight WT or KO mice had the L5 and L6 spinal nerve tightly ligated distal to the dorsal root ganglion but before the fibers joined the sciatic nerve; sham operation consisted of the same procedures but without the ligation. Mechanical thresholds were determined by measuring the paw withdrawal threshold to probing with a series of calibrated von Frey filaments as described above. Thermal thresholds were determined with the radiant heat test as described above. For the reversal of nerve injury-induced changes in mechanical and thermal thresholds, separate groups of five to eight mice were injected intrathecally with MK-801 (3.4 $\mu \mathrm{g}$ in $5 \mu \mathrm{l}$ saline), an antiserum against dynorphin $\mathrm{A}_{(1-17)}$, or a control nonimmune serum $(150 \mu \mathrm{g}$ in $5 \mu \mathrm{l})$ (Peninsula). This antiserum recognizes dynorphin $A_{(1-17)}$ and a number of its fragments and has no affinity for $\alpha$-neoendorphin, dynorphin B, $\beta$-endorphin, or $\left[\mathrm{Leu}^{5}\right]$ - or $\left[\mathrm{Met}^{5}\right]$ enkephalin. Reversal experiments were performed on days 2 and 14 after sham or SNL surgery. The latter time point was chosen to insure that testing was done at a time when behavioral baselines remained stable after return to preinjury levels in the KO mice (see below).

Statistical analysis. Comparison between groups were performed using Student's $t$ test. Statistical significance was established at 95\% confidence limit.

\section{RESULTS}

Initial analysis of spinal cord tissues from the WT mice showed that prodynorphin immunoreactivity is primarily located in the superficial laminae of the dorsal horn but is entirely absent in spinal cord tissues from the prodynorphin $\mathrm{KO}$ mice (Fig. 1). Enzyme immunoassay for the active peptide dynorphin $A_{(1-17)}$ which is one of the endogenous derivatives of prodynorphin, further confirmed the lack of dynorphin expression in the $\mathrm{KO}$ mice (see Fig. 5 below). The KO mice exhibited normal growth and development, feeding, motor function, and weight that were indistinguishable from their WT littermates. When these mice were evaluated for their nociceptive responsiveness, the WT and $\mathrm{KO}$ mice displayed similar latency to innocuous mechanical stimulation (Fig. 2A) as well as latencies to noxious input based on radiant heat and hot-plate tests (Fig. $2 C, D$ ). However, the $\mathrm{KO}$ mice consistently showed a small, but significant decrease in the tail-flick response latency when compared with the WT mice (Fig. $2 B)$. WT and KO mice were tested using a model of tonic nociceptive input by an injection of $2 \%$ formalin to the right hindpaw. Both the WT and KO mice displayed a biphasic flinching response over a $75 \mathrm{~min}$ period (Fig. 3). No difference was detected in the amplitude and duration of the first phase of

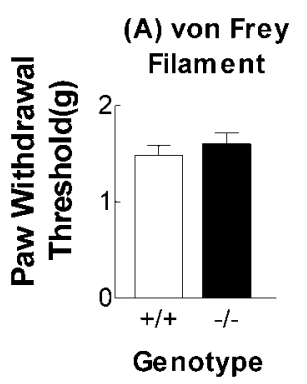

(C) Radiant Heat

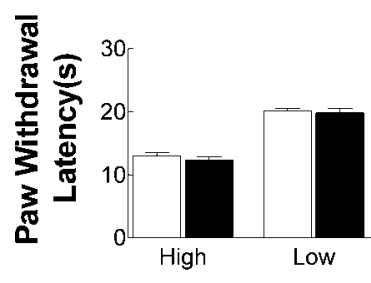

Heat Intensity

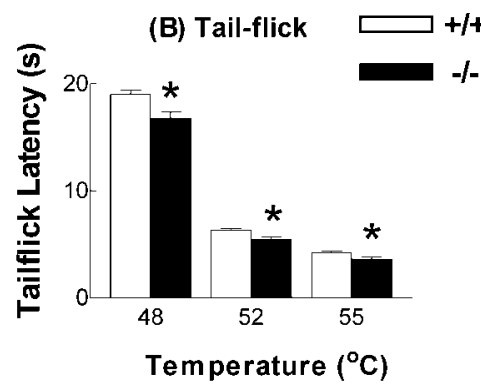

(D) Hot-plate

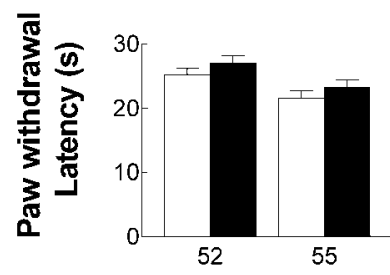

Temperature $\left({ }^{\circ} \mathrm{C}\right)$
Figure 2. Response thresholds of wild-type $(+/+)$ and prodynorphin knock-out $(-/-)$ mice to: innocuous mechanical stimulation of the paw with von Frey filaments ( $n=28$, each group) $(A)$; noxious thermal stimulus elicited by immersion of the tail in water at 48,52 , and $55^{\circ} \mathrm{C}(n=$ 32 , each group) $(B)$; noxious thermal stimulus of the paw with low- or high-intensity radiant heat ( $n=28$, each group) $(C)$; and hot plate latency at 52 or $55^{\circ} \mathrm{C}(n=28$, each group) $(D)$. Prodynorphin knock-out mice display small, but significantly shorter response latencies in the tail-flick test when compared with wild-type mice $\left({ }^{*} p<0.05\right)$, indicating mild hyperalgesia.

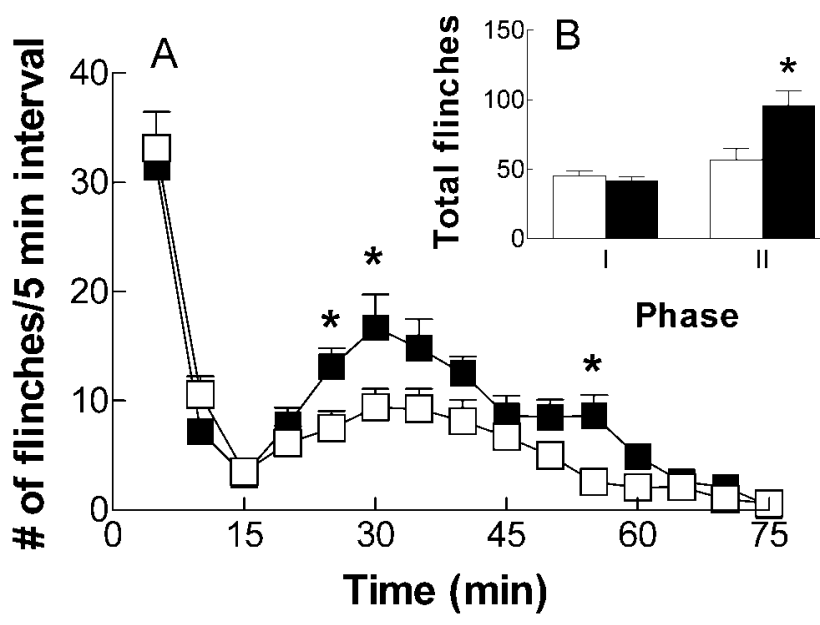

Figure 3. Formalin $(2 \%$, s.c.)-induced paw-flinching response in wildtype $(+/+)$ and prodynorphin knock-out $(-/-)$ mice. The time course of the formalin response is seen in $A$, and the total number of flinches in the first $(0-15 \mathrm{~min})$ and second (15-75 min) phases are seen in $B$. Prodynorphin knock-out mice exhibit a small but significantly greater number of paw flinches in the second phase of the formalin response when compared with wild-type mice $\left({ }^{*} p<0.05\right)$, suggesting mild hyperalgesia. Data represent the mean from 14 animals in each group.

flinching between the WT and KO mice (Fig. $3 A$ ). However, the $\mathrm{KO}$ mice showed a small, but significant enhancement of the second phase of flinching, indicated by the total number of flinches during the second phase compared with that exhibited by the WT mice over the same period (Fig. 3B). 

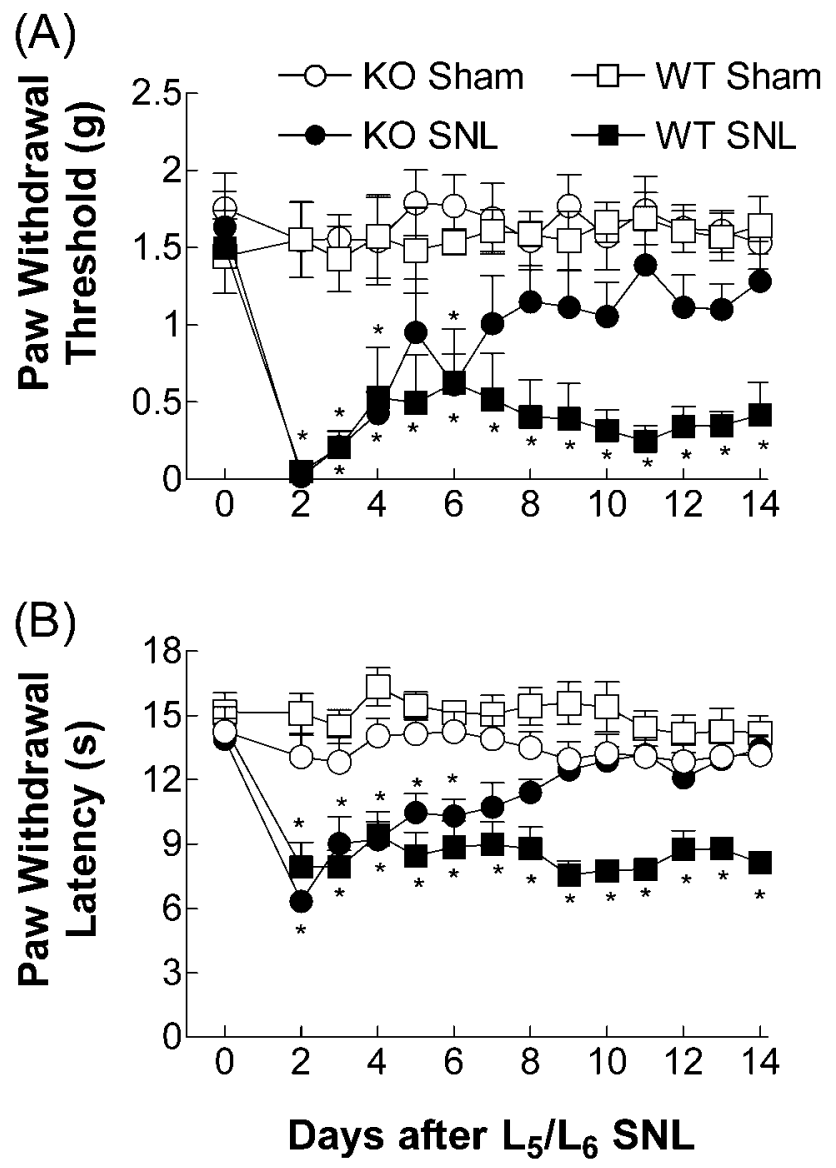

Figure 4. Response thresholds to innocuous mechanical (von Frey filaments) $(A)$ and noxious thermal (radiant heat applied to the paw) $(B)$ stimuli in wild-type (WT, squares) and prodynorphin knock-out (KO, circles) mice after sham (open symbols) or SNL surgery (closed circles). Neither WT nor KO mice show any change in the mechanical or thermal thresholds from preinjury baselines after sham surgery throughout the $14 \mathrm{~d}$ test period. After SNL, both WT and KO mice rapidly develop decreased innocuous mechanical and noxious thermal thresholds by postsurgery day 2 . Whereas the decreased mechanical and thermal thresholds were maintained in WT mice (closed squares), thresholds in $\mathrm{KO}$ mice showed a progressive reversal to preinjury baseline levels (closed circles). By day 10 after SNL, both mechanical and thermal thresholds in KO mice were not significantly different from those exhibited by sham-operated KO (or WT) mice done in parallel $(p>0.5)$. Asterisk denotes values that are significantly different from the corresponding sham-operated mice. Data represent the mean from eight mice in each experimental group.

The possible contribution of dynorphin in nerve injury-induced neuropathic pain states was investigated by comparing the development of decreased latency to respond to a noxious thermal stimulus and decreased response thresholds to innocuous mechanical stimulation after L5/L6 SNL injury in the WT or KO mice. Figure 4 shows that within $2 \mathrm{~d}$ after SNL injury, both the WT and KO mice developed pronounced increases in sensitivity to innocuous mechanical and thermal stimulation when compared with the sham-operated WT and KO mice. However, whereas the SNL-injured WT mice maintained increased mechanical and thermal sensitivity for the remaining time course (up to $14 \mathrm{~d}$ of continuous monitoring) of the experiment, the $\mathrm{KO}$ mice exhibited a progressive reversal of sensitivity to innocuous mechanical and noxious thermal stimulation such that by day 10 after SNL injury, the paw withdrawal threshold to radiant heat stimulus or

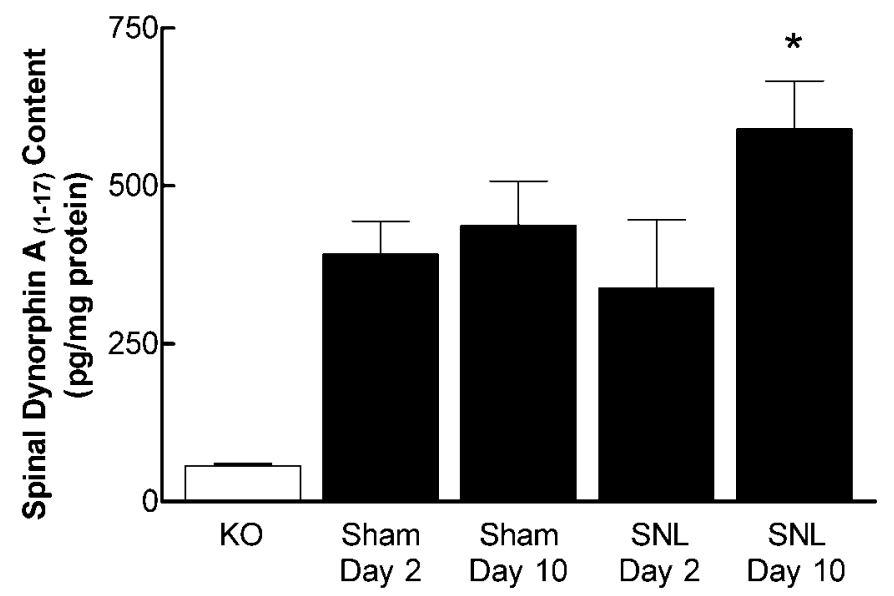

Figure 5. Quantitative analysis of spinal dynorphin content in prodynorphin KO and WT mice on days 2 and 10 after sham or SNL surgery. Extract from the dorsal ipsilateral quadrant of the lumbar spinal cord from each of five mice for each experimental group was used for the enzyme immunoassay. Prodynorphin KO mice showed negligible immunoreactivity. Similar levels of spinal dynorphin were seen in WT mice at day 2 after SNL or at days 2 or 10 after sham surgery, whereas spinal dynorphin was significantly increased in WT mice at day 10 after SNL $\left({ }^{*} p<0.05\right)$.

von Frey filament probing was not different from the preinjury level or that of the sham-operated controls.

Quantitative analysis of spinal dynorphin content by enzyme immunoassay showed that in the WT mice, spinal dynorphin at day 10 after SNL $(590 \pm 76 \mathrm{pg} / \mathrm{mg})$ was significantly elevated $(p<0.05)$ when compared with sham-operated controls $(390 \pm$ $74 \mathrm{pg} / \mathrm{mg})$, whereas at day 2 after SNL (340 $\pm 110 \mathrm{pg} / \mathrm{mg})$ spinal dynorphin was not different from the sham controls (Fig. 5). The immunoreactivity found in extracts from $\mathrm{KO}$ mice $(56 \pm 3 \mathrm{pg}$ / $\mathrm{mg}$ ) was negligible when compared with that in the WT mice and likely represents the nonspecific activity of the antiserum. To substantiate the possible involvement of spinal dynorphin in the observed neuropathic pain, WT and KO mice were subjected to SNL, and at days 2 and 14 after surgery, they received a bolus intrathecal injection of an antiserum to dynorphin and were then monitored for paw withdrawal thresholds to von Frey filaments (Fig. 6A) or radiant heat (Fig. 6B). Dynorphin antiserum had no effect on the enhanced sensitivity to innocuous mechanical or noxious thermal stimuli seen in the WT or KO mice $2 \mathrm{~d}$ after SNL, however, dynorphin antiserum reversed these decreased thresholds in the WT mice $14 \mathrm{~d}$ after SNL. Dynorphin antiserum had no effect on the responses of the KO mice $14 \mathrm{~d}$ after SNL, at which time the paw withdrawal thresholds for both innocuous and noxious stimuli had returned to preinjury level. Control serum did not alter baseline responses in any treatment groups (data not shown). The NMDA receptor antagonist, MK-801, was similarly used to evaluate the contribution of excitatory amino acid neurotransmission to neuropathic pain states in these mice (Fig. 6). In contrast to the data with intrathecal antiserum to dynorphin, intrathecal MK-801 was effective in reversing the decreased thresholds to innocuous mechanical and noxious thermal stimuli in WT and KO mice at day 2 after SNL and in WT mice at day 14 after SNL. MK-801 had no effect on the paw withdrawal thresholds to innocuous or noxious stimuli in the KO mice at day 14 after SNL. Neither dynorphin antiserum nor MK-801 altered paw withdrawal latencies in sham-operated WT or KO mice.

It has been recognized that an alteration of function of a 

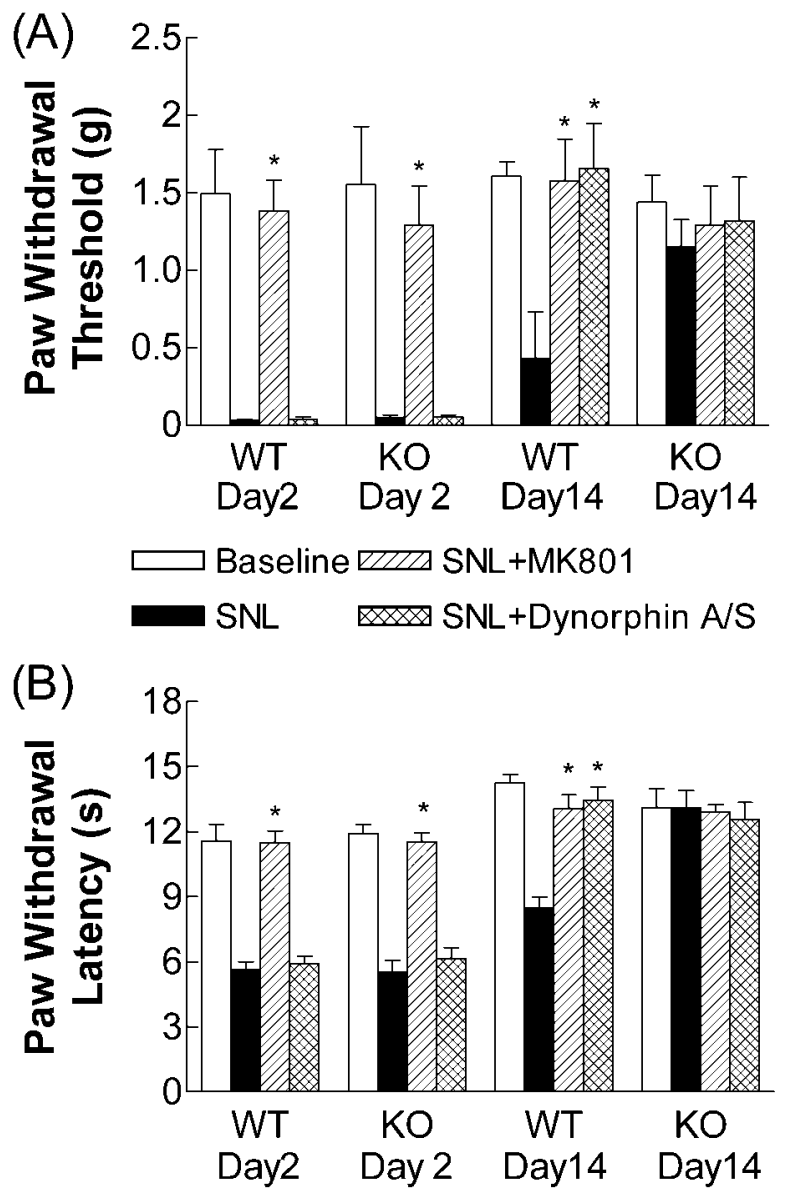

Figure 6. Effects of MK-801 and antiserum to dynorphin A (dynorphin $\mathrm{A} / \mathrm{S}$ ) on the response threshold to innocuous mechanical stimulation (von Frey filaments) $(A)$ and noxious thermal (radiant heat applied to the paw) stimulation $(B)$ in wild-type $(W T)$ and prodynorphin knock-out $(K O)$ mice. SNL induced a decrease in both mechanical and thermal thresholds in WT mice at days 2 and 14 after surgery and in $\mathrm{KO}$ mice at day 2, but not day 14, after SNL surgery. At day 2 after SNL, intrathecal MK-801 reversed the decreased mechanical and thermal response thresholds seen in both WT and KO mice (hatched bars); intrathecal dynorphin A/S (cross-hatched bars) had no effect at postsurgery day 2. At day 14 after SNL, both intrathecal MK-801 and dynorphin A/S reversed the SNLinduced decrease in mechanical and thermal response thresholds in WT mice. Prodynorphin KO mice no longer exhibit reduced thresholds at day 14 (Fig. 4), and intrathecal MK-801 or dynorphin A/S did not affect mechanical or thermal thresholds in these SNL-injured mice $\left({ }^{*} p<0.05\right)$. Data represent mean from five to eight mice in each experimental group.

particular gene in a transgenic organism could, during development, give rise to compensatory phenotypic changes that may undermine the experimental interpretation of the function of the gene in question. Pertinent to the present study is any potential compensation to a loss of dynorphin expression in the spinal cord that may influence sensory processing. Dynorphin is an endogenous opioid, suggesting that a lack of this peptide could elicit compensatory changes of opioid receptor expression or function resulting in an enhancement of processes of inhibition in sensory transmission. However, an evaluation of the total opioid receptors in the brain (Table 1), as well as the immunoreactivity of the $\kappa$ opioid receptor (see Fig. 8) and $\mu$ opioid receptor in the spinal cord (see Fig. 9), indicates that the density of opioid receptors, as well as their affinity to the opioid antagonist diprenorphine in the $\mathrm{KO}$ mice were not significantly different from that in the WT
Table 1. Saturation analysis of $\left[{ }^{3} \mathrm{H}\right]$ diprenorphine (a nonselective opioid receptor antagonist that labels $\mu, \delta$ and $\kappa$ opioid receptors) in cortical brain membranes from WT and prodynorphin KO mice

\begin{tabular}{llll} 
Genotype & Treatment $^{a}$ & $K_{\mathrm{D}}{ }^{b}(\mathrm{nM})$ & $\begin{array}{l}B_{\max }{ }^{c}(\mathrm{fmol} / \mathrm{mg} \\
\text { protein) }\end{array}$ \\
\hline WT & Sham & $0.67(0.42-1.04)$ & $179 \pm 26$ \\
\multirow{2}{*}{ KO } & SNL & $0.87(0.87-0.88)$ & $194 \pm 37$ \\
& Sham & $0.45(0.41-0.50)$ & $176 \pm 17$ \\
& SNL & $0.61(0.39-0.97)$ & $167 \pm 18$
\end{tabular}

$\overline{{ }^{a} \text { Mice were subjected to either sham or SNL surgery (see Materials and Methods), }}$ and tissues were harvested after $14 \mathrm{~d}$.

${ }^{b} K_{\mathrm{D}}$ values represent the mean from three independent experiments; the range of values is shown in parentheses.

${ }^{c} B_{\max }$ values represent the mean $\pm \mathrm{SEM}$ of the maximum specific binding of $\left[{ }^{3} \mathrm{H}\right]$ diprenorphine from three independent experiments.

mice. The density of the opioid receptors also did not change after SNL injury in the WT or KO mice. The potency and efficacy of the selective opioid agonists for $\mu, \delta$, and $\kappa$ receptors in stimulating $\gamma-\left[{ }^{35} \mathrm{~S}\right] \mathrm{GTP}$ binding to spinal cord membranes argue against any functional difference in these receptors between the WT and KO mice after sham or SNL surgery (Fig. 7). The expression and distribution of protein kinase $\mathrm{C} \gamma(\mathrm{PKC} \gamma)$, which has been implicated in the development of neuropathic pain (Malmberg et al., 1997), was also found to be similar in sham or SNL-injured WT and KO mice (see Fig. 9). However, the potency and efficacy of selective opioid agonists for $\mu, \delta$, and $\kappa$ receptors in stimulating $\gamma-\left[{ }^{35} \mathrm{~S}\right] \mathrm{GTP}$ binding to spinal cord membranes argue against any functional difference in these receptors between the WT and KO mice after sham or SNL surgery (Fig. 7). Furthermore, an evaluation of the total opioid receptors in the brain (Table 1), as well as $\kappa$ (Fig. 8) and $\mu$ opioid receptor immunoreactivity in the spinal cord (Fig. 9) indicates that the density of opioid receptors, as well as their affinity to the opioid antagonist, diprenorphine, in the $\mathrm{KO}$ mice were not significantly different from that in the WT mice. The density of the opioid receptors also did not change after SNL injury in the WT or KO mice. The expression and distribution of protein kinase $\mathrm{C} \gamma$ $(\mathrm{PKC} \gamma)$, which has been implicated in the development of neuropathic pain (Malmberg et al., 1997), was also found to be similar in sham or SNL-injured WT and KO mice (Fig. 9).

\section{DISCUSSION}

The generation of a transgenic mouse strain that does not express dynorphin allows for an assessment of the possible contributions of this peptide in normal sensory thresholds as well as in pathological pain states. When compared with WT controls, the KO mice showed normal behavior and development as well as normal sensitivity to non-noxious stimulation. Only slightly altered nocifensive thresholds to some noxious stimuli were observed, suggesting that spinal reflex and pain transmission pathways are intact. A consistent observation was mild, but significant hyperalgesia in the $\mathrm{KO}$ mice as shown by the decrease observed in tail-flick response latencies and the enhancement of flinching in the second phase of the formalin response. These observations suggest the possibility that constitutive levels of the products of prodynorphin produce a modest and limited tonic inhibition of nociceptive input, likely through opioid actions, as previously suggested with studies using dynorphin antiserum (Ossipov et al., 1996). The mild endogenous tone suggested by these observations is also consistent with the relatively low levels of dynorphin 


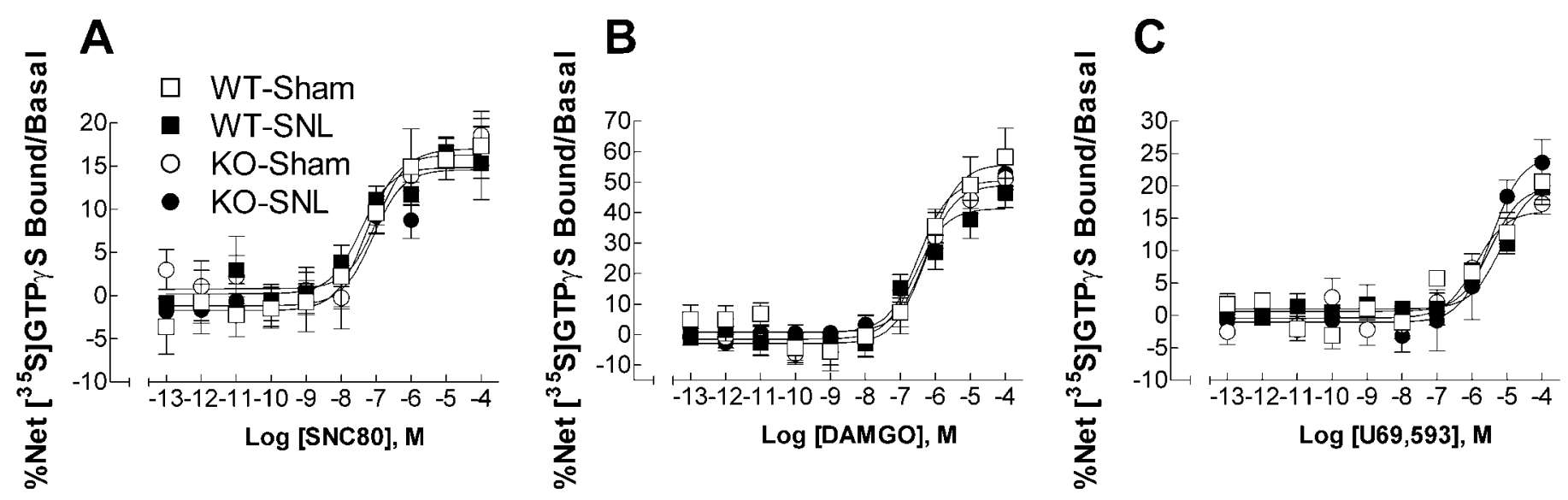

Figure 7. Stimulation of $\gamma-\left[{ }^{35} \mathrm{~S}\right] \mathrm{GTP}$ binding by the opioid $\delta$ receptor agonist SNC80 $(A)$, the opioid $\mu$ receptor agonist DAMGO $(B)$, and the opioid $\kappa$ receptor agonist U69,593 $(C)$ in spinal cord membranes prepared from WT (squares) or KO (circles) mice $14 \mathrm{~d}$ after sham (open symbols) or SNL surgery (closed symbols). No significant change in opioid receptor-mediated transduction was seen.

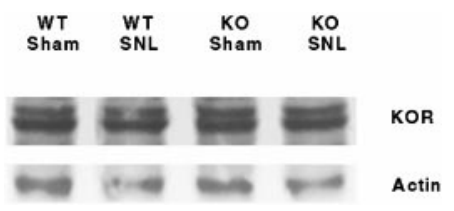

Figure 8. Western analysis of the opioid $\kappa$ receptor $(K O R)$ in lumbar spinal cord from wild-type $(W T)$ and prodynorphin knock-out $(K O)$ mice $14 \mathrm{~d}$ after sham or SNL surgery. The KOR antibody recognizes two bands of $\sim 50-55 \mathrm{kDa}$, and the antibody for actin recognizes a single band of 40 $\mathrm{kDa}$. The integrated optical densities for the KOR bands, normalized against that from the WT sham (1.0), are 0.92 for WT SNL, 0.93 for KO sham, and 1.0 for KO SNL, after correcting for loading based on the integrated optical density for actin in each sample. The data are representative of three separate analyses.

normally expressed in the spinal cord (Dubner and Ruda, 1992). However, it should be noted that in the initial characterization of these prodynorphin KO animals, Sharifi et al. (2001) found evidence for a reduced level of transcripts for proopiomelanocortin (POMC). The degree to which this change might affect peptide production remains to be determined, but the possibility that the mild hyperalgesia observed could also reflect a decrease in the expression of products of POMC, such as $\beta$-endorphin, cannot be excluded.

After SNL, both WT and KO mice demonstrated reliable signs of neuropathic pain within $2 \mathrm{~d}$, suggesting that the initiation of the postinjury state does not depend on the action of the products of prodynorphin. However, the WT mice exhibited a significant upregulation of spinal dynorphin at day 10 after SNL, which is similar to that previously observed in SNL-injured rats (Malan et al., 2000). This overexpression of spinal dynorphin notably correlates with the presence of sustained neuropathic pain in the SNL-injured WT mice, because in the SNL-injured KO mice in which spinal dynorphin is absent, a full recovery of increased sensitivity to innocuous mechanical and noxious thermal stimuli was observed by day 10 after injury. These findings support the possibility of a causal relationship between upregulated spinal dynorphin and the abnormal pain state. This possibility was tested further by spinal administration of dynorphin antiserum. Dynorphin antiserum has previously been shown to reverse SNLinduced neuropathic pain in rats (Malan et al., 2000) and in mice (Ibrahim et al., 1999). Consistent with the earlier observation in
$\operatorname{MOR}(A)$

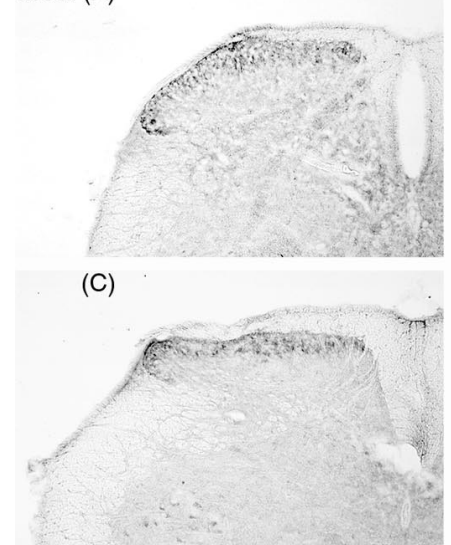

PKCY (E)

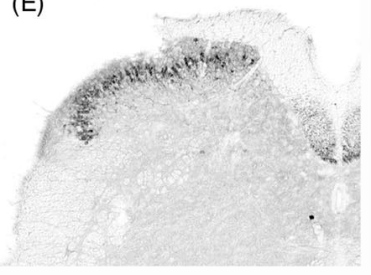

(G)

(B)

(D)
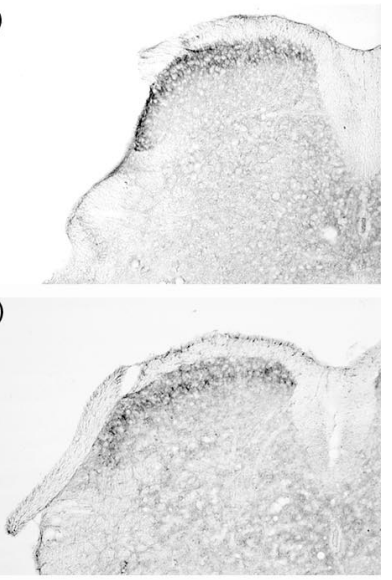

(F)

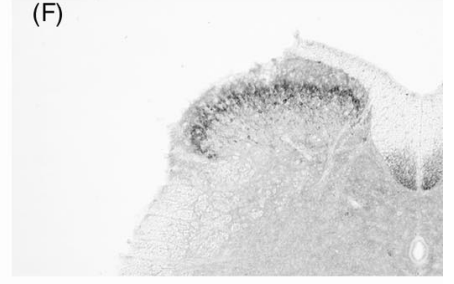

(H)

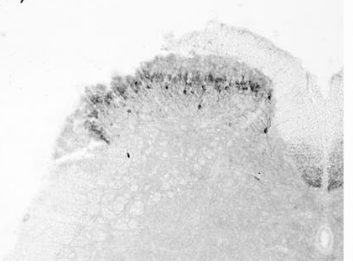

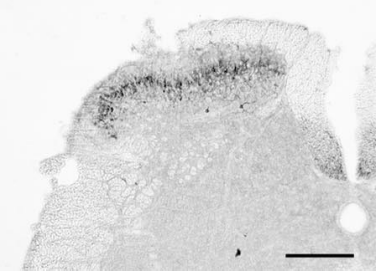

Figure 9. Opioid $\mu$ receptor $(M O R ; A-D)$ and protein kinase $\mathrm{C} \gamma(P K C \gamma$; $E-H)$ immunoreactivity in the ipsilateral dorsal horn of the lumbar spinal cord of wild-type (WT, left column) and prodynorphin knock-out (KO, right column $)$ mice, after sham surgery $(A, B ; E, F)$ or at day 14 after SNL $(C$, $D ; G, H)$. No qualitative difference in immunoreactivity was seen in tissues from WT and KO mice after sham or SNL surgery. Scale bar, $200 \mu \mathrm{m}$.

rats and mice, intrathecal dynorphin antiserum had no effect on sensory thresholds in sham-operated WT or KO mice (Ibrahim et al., 1999; Malan et al., 2000). When tested at day 2 after SNL injury, intrathecal dynorphin antiserum also did not affect sensory thresholds in WT or KO mice. When tested $14 \mathrm{~d}$ after SNL 
injury, however, intrathecal administration of antiserum to dynorphin completely reversed the increased sensitivity to innocuous mechanical and noxious thermal stimuli induced by SNL in WT mice (no pain or effects of dynorphin antiserum were seen in SNL KO mice at day 14). The time-related activity of dynorphin antiserum against SNL-induced pain contrasts sharply with the activity of intrathecal MK-801; this compound was effective in reversing SNL-induced pain when tested at either 2 or $14 \mathrm{~d}$ after injury. Critically, it should be noted that the reversal by dynorphin antiserum was to, but not above, preinjury baseline levels, indicating blockade of a pronociceptive effect rather than production of "analgesia."

The lack of sustained SNL-induced pain in the prodynorphin KO mice, together with the increased mechanical and thermal sensitivity of the SNL WT mice to dynorphin antiserum as well as MK-801 on day 14, have led us to conclude that the products of prodynorphin, and specifically dynorphin, are essential in the maintenance of the neuropathic pain state. The specific involvement of dynorphin in the SNL-induced pain, rather than that of other products of the prodynorphin gene, is supported by the specificity of the antiserum used as well as the demonstrated increases in expression of spinal dynorphin at day 10 after SNL. In this regard, it should be emphasized that the potential reduction of POMC products such as $\beta$-endorphin in these $\mathrm{KO}$ mice would be expected to increase sensitivity to pain, rather than promote the decrease in sensitivity to noxious or non-noxious stimuli observed in the current experiments. These data, together with the activity of dynorphin antiserum only at a time when spinal dynorphin is upregulated, strongly suggests that unlike dynorphin, potential deficiencies in the expression of POMC products do not play a role in the observed consequences of SNL injury.

The differential sensitivity to reversal of SNL-induced pain by MK-801, but not dynorphin antiserum at postinjury day 2, also indicates that the processes that initiate neuropathic pain differ from those that are critical to its maintenance. The activity of MK-801 underscores the likely importance of repetitive discharge originating from the injured or adjacent primary afferent neurons to initiate SNL-induced neuropathic pain (Seltzer et al., 1991). Ectopic discharge is known to occur and to peak within $16 \mathrm{hr}$ after SNL in rats but decreases over time to $<50 \%$ of its initial discharge rate by day 5 after injury (Han et al., 2000). Although the discharge rate of the injured nerve fibers depends on fiber type, it is clear that discharge rate diminishes with time after nerve injury (C. Liu et al., 2000; X. Liu et al., 2000). However, the magnitude of the observed signs of neuropathic pain are maintained essentially unchanged for many weeks (Chaplan et al., 1994; Bian et al., 1995; X. Liu et al., 2000). These findings suggest that mechanisms required to maintain the presence of the neuropathic pain state extend beyond afferent input to the CNS. Our data support this possibility and suggest that whereas ectopic activity is likely to drive the neuropathic pain state at early stages after nerve injury, afferent discharge is necessary but not sufficient to maintain the neuropathic pain state in the absence of an upregulation of spinal dynorphin. Thus, the data provide support for the concept that the processes which maintain the neuropathic pain state depend on the presence of increased levels of spinal dynorphin.

Dynorphin appears to maintain the neuropathic pain state ultimately through an NMDA-dependent mechanism. It might be speculated that elevated levels of dynorphin act to increase the release of excitatory transmitters from presynaptic and/or postsynaptic spinal sites, an idea that awaits experimental validation. However, the des-Tyr fragments of dynorphin (i.e., nonopioid fragments) have been demonstrated to enhance capsaicinevoked release of calcitonin gene-related peptide from primary afferent fibers in spinal cord preparations (Claude et al., 1999; T. Vanderah and F. Porreca, unpublished observations) and in DRG cells in culture (J. Lai, Z. Wang, and F. Porreca, unpublished observations). Des-Tyr dynorphin also activates PKC in spinal cord (Z. Wang, F. Porreca, and J. Lai, unpublished observations) and stimulates an increase in intracellular calcium in neuronal cells (Tang et al., 2000). Additionally, it is known that dynorphin and its fragments may directly bind to the NMDA receptor (Tang et al., 1999) although the physiological relevance of such binding is unclear. An interesting and plausible hypothesis is that SNLinduced afferent discharge may initiate the consequences of nerve injury, including an upregulation of spinal dynorphin that ultimately acts to sustain the SNL-induced pain. This would be in line with an early, dynorphin-independent, and a later, dynorphin-dependent, neuropathic pain state as a result of SNL.

An alternate explanation may relate to the possibility that SNL injury results in an upregulation of inhibitory transmitter-receptor systems. Using a model of sustained inflammatory pain, Dubner and colleagues have suggested that inhibitory receptors (such as opioid $\delta$ receptors) may be upregulated in opioid $\mu$ receptordeficient mice (Qiu et al., 2000). An examination of opioid receptor expression and transduction in the post-SNL injury state revealed no changes, suggesting that such compensations were not responsible for the progressive reversal of neuropathic pain in the KO mice.

The present study supports the concept that an upregulation of dynorphin results in a pathological action that is pronociceptive and acts to maintain the chronic pain state. These findings offer a potentially important alternative to the development of NMDA antagonists as treatments for neuropathic pain. Whereas the latter are likely to be limited by a broad spectrum of severe side effects (Blanchet et al., 1997), approaches that may selectively limit the increased expression or activity of dynorphin may offer pain relief without associated side effects. The findings from this study reveal a previously unknown role of dynorphin to promote pain. Dynorphin may also participate in other pathological states associated with injuries to peripheral or central nerves, including the consequences of ischemia, stroke, and central trauma (Faden, 1996). Critically, our data suggest that a blockade of an overexpression of dynorphin or its actions may represent a new modality to interfere with the maintenance of chronic pain, which remains one of the most important challenges to clinical medicine.

\section{REFERENCES}

Bian D, Nichols ML, Ossipov MH, Lai J, Porreca F (1995) Characterization of the antiallodynic efficacy of morphine in a model of neuropathic pain in rats. NeuroReport 6:1981-1984.

Bian D, Ossipov MH, Ibrahim M, Raffa RB, Tallarida RJ, Malan Jr TP, Lai J, Porreca F (1999) Loss of antiallodynic and antinociceptive spinal/supraspinal morphine synergy in nerve-injured rats: restoration by MK-801 or dynorphin antiserum. Brain Res 831:55-63.

Blanchet PJ, Papa SM, Metman LV, Mouradian MM, Chase TN (1997) Modulation of levodopa-induced motor response complications by NMDA antagonists in Parkinson's disease. Neurosci Biobehav Rev 21:447-453.

Chaplan SR, Bach FW, Pogrel JW, Chung JM, Yaksh TL (1994) Quantitative assessment of tactile allodynia in the rat paw. J Neurosci Methods 53:55-63.

Claude P, Gracia N, Wagner L, Hargreaves KM (1999) Effect of dynorphin on ICGRP release from capsaicin-sensitive fibers. In: Abstracts of the ninth world congress on pain, p 262. Vienna: IASP.

Devor M, Seltzer Z (1999) Pathophysiology of damaged nerves in rela- 
tion to chronic pain. In: Textbook of pain (Wall PD, Melzack R, eds), pp 129-164. London: Churchill Livingstone.

Dixon WJ (1980) Efficient analysis of experimental observations. Annu Rev Pharmacol Toxicol 20:441-462.

Dubner R, Ruda MA (1992) Activity-dependent neuronal plasticity following tissue injury and inflammation. Trends Neurosci 15:96-103.

Faden AI (1996) Neurotoxic versus neuroprotective actions of endogenous opioid peptides: implications for treatment of CNS injury. NIDA Res Monogr 163:318-330.

Goldstein A, Tachibana S, Lowney LI, Hunkapiller M, Hood L (1979) Dynorphin-(1-13), an extraordinarily potent opioid peptide. Proc Natl Acad Sci USA 76:6666-6670.

Han HC, Lee DH, Chung JM (2000) Characteristics of ectopic discharges in a rat neuropathic pain model. Pain 84:253-261.

Hargreaves K, Dubner R, Brown F, Flores C, Joris J (1988) A new and sensitive method for measuring thermal nociception in cutaneous hyperalgesia. Pain 32:77-88.

Iadarola MJ, Douglass J, Civelli O, Naranjo JR (1988) Differential activation of spinal cord dynorphin and enkephalin neurons during hyperalgesia: evidence using cDNA hybridization. Brain Res 455:205-212.

Ibrahim M, Vanderah TW, Gardell LR, Zhong CM, Malan TP, Lai JL, Porreca F (1999) Repeated spinal opioid administration or peripheral nerve injury elicits abnormal pain in ICR, but not PKC $\gamma \mathrm{KO}$ or 129SvEv, mice. Soc Neurosci Abstr 25:925.

Kajander KC, Bennett GJ (1992) Onset of a painful peripheral neuropathy in rat: a partial and differential deafferentation and spontaneous discharge in A beta and A delta primary afferent neurons. J Neurophysiol 68:734-744.

Kim SH, Chung JM (1992) An experimental model for peripheral neuropathy produced by segmental spinal nerve ligation in the rat. Pain 50:355-363.

Lai SL, Gu Y, Huang LY (1998) Dynorphin uses a non-opioid mechanism to potentiate $N$-methyl-D-aspartate currents in single rat periaqueductal gray neurons. Neurosci Lett 247:115-118.

Laughlin TM, Vanderah TW, Lashbrook J, Nichols ML, Ossipov M, Porreca F, Wilcox GL (1997) Spinally administered dynorphin A produces long-lasting allodynia: involvement of NMDA but not opioid receptors. Pain 72:253-260.

Liu C, Wall PD, Ben-Dor E, Michaelis M, Amir R, Devor M (2000) Tactile allodynia in the absence of $\mathrm{C}$-fiber activation: altered firing properties of DRG neurons following spinal nerve injury. Pain 85:503-521.

Liu X, Eschenfelder S, Blenk KH, Janig W, Habler H (2000) Spontaneous activity of axotomized afferent neurons after L 5 spinal nerve injury in rats. Pain 84:309-318.

Malan TP, Ossipov MH, Gardell LR, Ibrahim M, Bian D, Lai J, Porreca F (2000) Extraterritorial neuropathic pain correlates with multiseg- mental elevation of spinal dynorphin in nerve-injured rats. Pain 86:185-194.

Malmberg AB, Brandon EP, Idzerda RL, Liu H, McKnight GS, Basbaum AI (1997) Diminished inflammation and nociceptive pain with preservation of neuropathic pain in mice with a targeted mutation of the type I regulatory subunit of cAMP-dependent protein kinase. J Neurosci 17:7462-7470.

Massardier D, Hunt PF (1989) A direct non-opiate interaction of dynorphin-(1-13) with the $N$-methyl-D-aspartate (NMDA) receptor. Eur J Pharmacol 170:125-126.

Ossipov MH, Kovelowski CJ, Wheeler-Aceto H, Cowan A, Hunter JC, Lai J, Malan Jr TP, Porreca F (1996) Opioid antagonists and antisera to endogenous opioids increase the nociceptive response to formalin: demonstration of an opioid kappa and delta inhibitory tone. J Pharmacol Exp Ther 277:784-788.

Ossipov MH, Lai J, Malan TP, Porreca F (1999) Opioid analgesic activity in neuropathic pain states. In: Opioid sensitivity of chronic noncancer pain (Kalso E, McQuay JJ, Wiesenfeld-Hallin Z, eds), pp 163-181. Seattle: IASP.

Porreca F, Tang Q, Bian D, Riedl M, Elde R, Lai J (1998) Spinal opioid mu receptor expression in lumbar spinal cord of rats following nerve injury. Brain Res 795:197-203.

Qiu C, Sora I, Ren K, Uhl G, Dubner R (2000) Enhanced delta-opioid receptor-mediated antinociception in mu-opioid receptor-deficient mice. Eur J Pharmacol 387:163-169.

Seltzer Z, Beilin BZ, Ginzburg R, Paran Y, Shimko T (1991) The role of injury discharge in the induction of neuropathic pain behavior in rats. Pain 46:327-336.

Sharifi N, Diehl N, Yaswen L, Brennan MB, Hochgeschwender U (2001) Generation of dynorphin knockout mice. Mol Brain Res, in press.

Skilling SR, Sun X, Kurtz HJ, Larson AA (1992) Selective potentiation of NMDA-induced activity and release of excitatory amino acids by dynorphin: possible roles in paralysis and neurotoxicity. Brain Res $575: 272-278$.

Tang Q, Gandhoke R, Burritt A, Hruby VJ, Porreca F, Lai J (1999) High-affinity interaction of (des-Tyrosyl)dynorphin A(2-17) with NMDA receptors. J Pharmacol Exp Ther 291:760-765.

Tang Q, Lynch RM, Porreca F, Lai J (2000) Dynorphin A elicits an increase in intracellular calcium in cultured neurons via a non-opioid, non-NMDA mechanism. J Neurophysiol 83:2610-2615.

Vanderah TW, Laughlin T, Lashbrook JM, Nichols ML, Wilcox GL, Ossipov MH, Malan Jr TP, Porreca F (1996) Single intrathecal injections of dynorphin A or des-Tyr-dynorphins produce long-lasting allodynia in rats: blockade by MK-801 but not naloxone. Pain 68:275-281.

Vanderah TW, Gardell LR, Burgess SE, Ibrahim M, Dogrul A, Zhong CM, Zhang ET, Malan TP, Ossipov MH, Lai J, Porreca F (2001) Dynorphin promotes abnormal pain and spinal opioid antinociceptive tolerance. J Neurosci 21:279-286. 